\title{
The role of alliances in leveraging national local content policies for firm competitiveness
}

Article

Accepted Version

Belitski, M., Kalyuzhnova, Y. and Azhgaliyeva, D. (2017) The role of alliances in leveraging national local content policies for firm competitiveness. International Journal of Strategic Business Alliances, 6 (1/2). pp. 69-85. ISSN 1756-6452 doi: https://doi.org/10.1504/IJSBA.2017.089844 Available at https://centaur.reading.ac.uk/74796/

It is advisable to refer to the publisher's version if you intend to cite from the work. See Guidance on citing.

To link to this article DOI: http://dx.doi.org/10.1504/IJSBA.2017.089844

Publisher: Inderscience Publishers

All outputs in CentAUR are protected by Intellectual Property Rights law, including copyright law. Copyright and IPR is retained by the creators or other copyright holders. Terms and conditions for use of this material are defined in the End User Agreement.

www.reading.ac.uk/centaur 
Central Archive at the University of Reading

Reading's research outputs online 


\title{
The role of alliances in leveraging national local content policies for firm competitiveness
}

\section{Maksim Belitski ${ }^{*}$ and Yelena Kalyuzhnova}

Henley Business School,

University of Reading,

Whiteknights, Reading, RG6 6UB, UK

Email: m.belitski@reading.ac.uk

Email: y.kalyuzhnova@henley.ac.uk

${ }^{*}$ Corresponding author

\section{Dina Azhgaliyeva}

Energy Studies Institute,

National University of Singapore,

21 Lower Kent Ridge Rd,

Singapore 119077, Singapore

Email: dina.azhgaliyeva@nus.edu.sq

\begin{abstract}
This study investigates the role of alliances in leveraging local content policies (LCPs) for firm competitiveness. In international markets where competition is strong, firms that are part of a group may demonstrate a higher level of competitiveness. Analysis of Kazakhstani firms over two periods, 2009 and 2013, before and after implementation of the local content policy outlines the importance of alliances as a conduit of knowledge and resources.
\end{abstract}

Keywords: alliance; firm performance; developing country; local content policy, Kazakhstan.

Reference to this paper should be made as follows: Belitski, M., Kalyuzhnova, Y. and Azhgaliyeva, D. ( $x x x x)$ 'The role of alliances in leveraging national local content policies for firm competitiveness', Int. J. Strategic Business Alliances, Vol. x, No. x, pp.xxx-xxx.

Biographical notes: Maksim Belitski is an Associate Professor at the Henley Centre for Entrepreneurship (HCfE), University of Reading. Prior to joining Henley, he was a Research Fellow at the Institute for Development Strategies, Indiana University Bloomington (US) and a Contract Professor of Econometrics at the University of Bolzano (Italy). His major research interests are in entrepreneurship, managerial economics, research methods, quantitative methods for business and finance, econometrics. He holds a $\mathrm{PhD}$ in Social Sciences from the University of Leicester (UK) and Milan (Italy).

Yelena Kalyuzhnova has worked as an Economic Adviser to the President of Kazakhstan. She founded and is the Director of the Centre for Euro-Asian Studies at the University of Reading. She has a wide knowledge of the transition and emerging economies, was an Economic Adviser on Caspian issues to the Rt. Hon. Lord Fraser of Carmyllie, Q.C., House of Lords and 
an Economic Adviser to All-Party Parliamentary Group on Kazakhstan (2006-2010). She is currently a Senior Visiting Research Fellow at the Oxford Institute for Energy Studies.

Dina Azhgaliyeva is a Research Fellow at the National University of Singapore in July 2017. Prior to joining the NUS, she was a Research Fellow at the University of Reading (UK), where she was involved in the empirical analysis of the impact of local content policy on extractive industries. Her work also involved communication with policy makers, extractive industry and oil and gas service companies. In 2012-2015, she was an Economics Teaching Fellow at the University College London. She also worked as a Chief Specialist at the Ministry of Finance of Kazakhstan. She holds a PhD in Economics, Master in Economics and Graduate Diploma in Economics, all from the University of Essex (UK).

\section{Introduction}

Research on alliances and national economic policies has been part of the strategic management and economic development literature (Eisinger, 1995; Bradshaw and Blakely, 1999). The formation of alliances could become an efficient mechanism in addressing changes of local governance (Platteau and Gaspart, 2003; Díaz-Cayeros et al., 2014) and redesigning strategies under protectionist policies (Pekar and Allio, 1994). The role of alliances and firm ownership in responding to policies related to supporting local manufacturers, also known as local content policies (LCPs) (Enderwick, 2011; Tordo et al., 2013) is observed in most emerging economies. LCPs may change the business environment and market-entry modes, along with changing the competitiveness of domestic and foreign firms, affecting the catching up with a learning process across countries and industries (Malerba and Nelson, 2011). Understanding the strategies that alliances can use to benefit from LCPs has merely been a subject of research in strategic management (Pekar and Allio, 1994; Hipkin and Naudé, 2006). Emerging strategies for alliances to respond to national LCPs have also been an important issue in the international business literature (Pan et al., 1999).

In this paper, we analyse the effect of national protectionist policies, such as LCPs, on domestic firms' competitiveness and the role that alliances play in leveraging this effect. Our analysis is based on Kazakhstan (a resource-rich emerging economy) where LCPs have recently been implemented.

LCPs are perceived as industrial and community-development tools that enable domestic producers to expand their activities, at least partially, with domestic inputs, and gain access to international technological and managerial expertise (Kalyuzhnova et al., 2016). LCPs may challenge long-term strategies of firms that are part of alliances (Devlin and Bleackley, 1988).

LCPs "belong to a set of industrial policies that have the potential to incentivise value-added production and innovation-led growth when embedded within NISs [national innovation systems] that incentivise knowledge creation and diffusion" (Kalyuzhnova et al., 2016, p.220), as well as raising local labour capabilities. Factors and concepts that enable the building of stronger capabilities can help in achieving superior alliance performance (Draulans and Volberda, 2003). 
First, we demonstrate the importance of LCPs for domestic firms' competitiveness and juxtapose this with alliances. Second, we provide the first formal analysis of the implementation of LCPs in emerging resource-rich countries. The paper is structured as follows. Section 1 provides an introduction. Section 2 reviews prior research on alliances and LCPs - and a number of hypotheses are derived. Section 3 describes the data and chosen research design. Section 4 presents and discusses the results of our analysis. Section 5 provides the conclusion.

\section{Theory and hypotheses}

\subsection{Local content policies: existing concepts and types}

LCPs are often perceived by international companies as a cost of doing business and as market entry barrier (Deardorff and Stern, 1997; Heum et al., 2003; Kalyuzhnova, 2008). It also might be costly for governments to pursue LCPs. However, in the longer term, LCPs could benefit all players. In order for such benefits to emerge, not only are optimal LCP settings required, but it is important that LCPs make an impact on sustainable firm performance (such as export orientation) and ultimately lead to a competitive local industry that is resilient in the long run (Grossman, 1981).

Kalyuzhnova et al. (2016) argue that LCPs often aim to facilitate technology and knowledge transfer to the countries using this tool in order to enable development of new industries, and some countries (e.g., UK, Norway, and, partially, Brazil) have achieved this aim - creating domestic technology leaders as the basis for new product development. The effectiveness and impact of LCPs vary from country to country. Our analysis will be based on the methodology of a broad taxonomy of three LC 'types,' each of which identifies a particular dimension of LC (Kalyuzhnova et al., 2016).

According to this classification, the first type is market-creating $L C$ - where the country has no or little pre-existing sectoral expertise. This period is one of learning and generating domestic capacity. At this stage, LCPs play a crucial role in ensuring a domestic market for a new industry that over time may transform such industries into being more competitive. There are specific things here that would make a significant impact on market-creating LC, namely a government that creates an optimal economic basis (without harming the public or market players), entrepreneurs who identify gaps and industry need, and an exit strategy from LCPs (which should be finite) - the components of which enable further steps in promoting innovation and efficiency.

The second type, sustaining $L C$, represents the next stage in LC development, where the main point is to assist local producers in sustaining their production or market share in a domestic market.

Efficiency $L C$ represents the third type and its target is to expand local economic activity as well as develop an internationally competitive industry, which may not only substitute imports but increase exports. In other words, LCPs become a preferential treatment instrument for companies with latent comparative advantage, enabling companies to deepen their product development, increase value added, and expand internationally. Efficiency LC is a long-term process with a pay-off in the future; it is the most sophisticated type of LC. 


\subsection{Firms and local content policies}

LC is considered by many countries as a protectionist industrial tool in addressing a fundamental challenge: to increase domestic firms' competitiveness and foster sustainable economic growth through industrial diversification. Industrial diversification of the economy is a particular challenge for resource-rich countries (Gylfason et al., 1999; Fasano, 2002; Bastida, 2014; Farooki and Kaplinsky, 2014; Kalyuzhnova and Patterson, 2016) where governments need to determine how industries and new business could be supported by addressing the barriers to growth (Lin and Chang, 2009; Audretsch et al., 2015).

Some country cases demonstrate the inception of LCPs in the oil and gas $(O \& G)$ sector and only later did the spillover of such policies take place in a whole supply chain (Kalyuzhnova and Lee, 2014; Kalyuzhnova et al., 2016). In some cases, LCPs became a universal mechanism in boosting the functioning and diversification of local industries (Chu, 2011; Hunter, 2014). In this respect structure, scalability, and diversification needed to be taken into account by LCPs when assisting local firms' and industries' strengths and weaknesses.

Hypothesis 1: Local content policies increases firms' competitiveness.

\subsection{Alliances, local content policies, and the competitiveness nexus of the firm}

There are important challenges for firm competitiveness that enable the higher efficiency of LCPs.

First, structure and capacity are big issues for LC. Many firms do not have the structures or the capacities to survive (that might depend on their maturity, age, or other relevant firm characteristics). For example, if firms are not able to obtain International Organisation for Standardisation standards, they face serious barriers in participating in global or even local supply chains. The role of governments here would be in providing initial assistance for market-creating $L C$ conditions (Belitski and Desai, 2016).

Second, the biggest challenge in scaling up (firm size) is a lack of financial and market knowledge. Information, support, and resources could be provided from partners within an alliance (Hipkin and Naudé, 2006).

Third, investment is required to build managerial capacity, but it is challenging for domestic firms to access the required finance (Korosteleva and Mickiewicz, 2011). Firms need a favourable environment and governmental commitment to support sustaining $L C$. Production diversification, firms' survival, and the introduction of new products remain the most challenging issues (Capello and Lenzi, 2014). How these questions are addressed will determine the success of efficiency $L C$, leading firms to more competitive and sustainable functioning.

Recent research has demonstrated that cooperative activities facilitate firm performance internationally (Knight, 2000; Jantunen et al., 2005; Brouthers et al., 2015) with alliances providing access to finance and resources to improve international performance in an emerging economy ( $\mathrm{Lu}$ et al., 2010). Access to important resources, such as managerial or financial, under the condition of LCPs will be more a domestic market orientated. With high international competition (Street and Cameron, 2007; Brouthers et al., 2015) more firms will serve the domestic market, thus international competitiveness will fall. 
Hypothesis 2: Alliances negatively moderate the relationship between firms' competitiveness and implementation of local content policy.

\section{Research design}

\subsection{Sample and data sources}

We test our hypotheses using firm data from the World Bank's Enterprise Surveys for two cross-sections: in 2009 associated with the period before the adoption of LCP; and in 2013 after its introduction. Our sample includes 1059 Kazakhstani firms. Surveys are based on face-to-face interviews and provide information on firms' performance (such as export, sales, and employment). To compare and contrast the effect of LCPs on competitiveness we used the most recent data of 502 firms in 2009 and 557 firms in 2013. The firms that were surveyed in 2009 and 2013 are two rotated surveys. Each survey covered a three-year period (2007-2009 and 2011-2013) and the survey questionnaires were identical in all surveys for Kazakhstan. The firms in the survey were selected using a sampling design stratified by geographical area, industry, and firm size. We merged the data from the two World Bank surveys, 2009 and 2013, with regional socio-economic data for Kazakhstan following the World Bank's classification and theoretical framework of Estrin et al. (2013). We excluded firms with incomplete information or with extreme observations for the variables of interest. Table 1 illustrates the list of dependent and independent variables, while Table 2 provides summary statistics for the two survey periods (2009 and 2013) in a rolling sample of Kazakhstani firms.

Table 1 Data description and sources

\begin{tabular}{|c|c|c|}
\hline Variable & Description & Source \\
\hline \multicolumn{3}{|l|}{ Dependent variable } \\
\hline $\begin{array}{l}\text { Export - dependent } \\
\text { variable Model - step } 1\end{array}$ & $\begin{array}{l}\text { Share of exports in sales, \% (dependent } \\
\text { variable equation (5)) }\end{array}$ & $\begin{array}{l}\text { World Bank } \\
\text { Enterprise survey }\end{array}$ \\
\hline $\begin{array}{l}\text { Competitiveness gap - } \\
\text { dependent variable }\end{array}$ & $\begin{array}{l}\text { Difference between actual export and } \\
\text { fitted export from equation (5) }\end{array}$ & http://ebrd-beeps.com \\
\hline \multicolumn{3}{|l|}{ Model - step 2} \\
\hline \multicolumn{3}{|l|}{ Independent variables } \\
\hline \multicolumn{3}{|l|}{$\begin{array}{l}\text { Trade equity for } \\
\text { resources }\end{array}$} \\
\hline Foreign ownership & $\begin{array}{l}\text { Share of ownership that belongs to } \\
\text { foreigners }(\%)\end{array}$ & \\
\hline \multicolumn{3}{|l|}{ Trade debt for resources } \\
\hline Credit line & $\begin{array}{l}\text { Dummy variable equals } 1 \text { if a firm has a } \\
\text { credit line from financial institution }\end{array}$ & \\
\hline $\begin{array}{l}\text { Draw on stock of } \\
\text { resources }\end{array}$ & & \\
\hline
\end{tabular}


Table 1 Data description and sources (continued)

\begin{tabular}{|c|c|c|}
\hline Variable & Description & Source \\
\hline Size & $\begin{array}{l}\text { World Bank classification: small firms } \\
\text { ( }<20 \text { employees), medium firms (20-99 } \\
\text { employees), large firms ( } \geq 100 \\
\text { employees) }\end{array}$ & \\
\hline Age & Age of firms at the year of survey, years & \\
\hline Manager experience & $\begin{array}{l}\text { Number of years of manager's experience } \\
\text { in the current sector }\end{array}$ & \\
\hline CEO female & $\begin{array}{l}\text { Dummy variable equals } 1 \text { if top manager } \\
\text { is female }\end{array}$ & \\
\hline \multicolumn{3}{|l|}{ Creative strategies } \\
\hline ICT & $\begin{array}{l}\text { Dummy variable equals } 1 \text { if email or web } \\
\text { is used to communicate with customers or } \\
\text { suppliers }\end{array}$ & \\
\hline Alliance & $\begin{array}{l}\text { Dummy variable equals } 1 \text { if firm is a part } \\
\text { of an alliance }\end{array}$ & \\
\hline Patent & $\begin{array}{l}\text { Number of patents in a region where the } \\
\text { firm is located }\end{array}$ & \\
\hline $\begin{array}{l}\text { International market } \\
\text { access }\end{array}$ & $\begin{array}{l}\text { Dummy variable equals } 1 \text { if firm has an } \\
\text { internationally recognised quality } \\
\text { certificate }\end{array}$ & \\
\hline Industry & $\begin{array}{l}\text { Dummy variables indicating industries, } \\
\text { i.e., textiles, garments, food, metals and } \\
\text { machinery, electronics, chemicals and } \\
\text { pharmaceutics, wood and furniture, non- } \\
\text { metallic and plastic materials, other } \\
\text { manufacturing, other services, retail and } \\
\text { wholesale trade, hotels and restaurants, } \\
\text { auto and auto components, other: } \\
\text { construction, transportation, etc. }\end{array}$ & \\
\hline \multicolumn{3}{|l|}{ Region } \\
\hline SME density & $\begin{array}{l}\text { SME density (number of SMEs per } 1000 \\
\text { residents in region) }\end{array}$ & \multirow{6}{*}{$\begin{array}{l}\text { Committee on } \\
\text { Statistics of } \\
\text { Kazakhstan } \\
\text { www.stat.gov.kz }\end{array}$} \\
\hline Unemployment & Unemployment ratio, $\%$ & \\
\hline Transportation & $\begin{array}{l}\text { Share of GDP generated by } \\
\text { transportation, } \%\end{array}$ & \\
\hline Agriculture & Share of GDP generated by agriculture, $\%$ & \\
\hline ICT & Share of GDP generated by ICT, $\%$ & \\
\hline$G D P$ & $\begin{array}{l}\text { GDP per capita constant prices } 2005 \text {, } \\
\text { thousand US dollars }\end{array}$ & \\
\hline Universities & Number of universities & \\
\hline$L C P$ & $\begin{array}{l}\text { Dummy variable equals } 1 \text { if year equals } \\
2010\end{array}$ & Authors' calculation \\
\hline
\end{tabular}


The role of alliances in leveraging national local content policies

Table 2 Summary statistics by two survey periods $(N=1059)$

\begin{tabular}{lcccccc}
\hline & \multicolumn{5}{c}{ Wave $=2009$} & Wave $=2013$ \\
\cline { 2 - 6 } Variable & Obs & Mean & Std. dev. & Obs & Mean & Std. dev. \\
\hline \multicolumn{7}{c}{ Firm characteristics } \\
Competitiveness gap & 502 & 3.56 & 22.68 & 557 & 2.28 & 17.50 \\
Size & 502 & 1.12 & 8.01 & 557 & 1.02 & 8.22 \\
Age & 502 & 2.01 & 0.76 & 557 & 1.62 & 0.69 \\
Foreign ownership & 502 & 9.62 & 6.77 & 557 & 11.83 & 8.42 \\
Quality certificate & 502 & 4.36 & 18.83 & 557 & 2.88 & 15.76 \\
Manager experience & 502 & 0.82 & 0.39 & 557 & 0.82 & 0.39 \\
CEO female & 502 & 13.13 & 9.77 & 557 & 13.89 & 9.62 \\
Group & 502 & 0.24 & 0.43 & 557 & 0.23 & 0.42 \\
IT & 502 & 0.88 & 0.33 & 557 & 0.89 & 0.31 \\
\hline & 502 & 0.77 & 0.42 & 557 & 0.90 & 0.29 \\
\hline Unemployment & \multicolumn{7}{c}{ Regional characteristics } & & & \\
Transportation & 10 & 6.50 & 0.21 & 10 & 5.18 & 0.09 \\
Agriculture & 10 & 14.70 & 2.83 & 10 & 13.72 & 2.07 \\
ICT & 10 & 12.17 & 5.84 & 10 & 10.87 & 4.79 \\
GDP & 10 & 0.15 & 0.10 & 10 & 0.22 & 0.12 \\
SME & 10 & 5.56 & 2.83 & 10 & 7.73 & 2.96 \\
University & 10 & 5.59 & 0.52 & 10 & 6.65 & 0.91 \\
\hline & 10 & 33.91 & 25.39 & 10 & 35.43 & 24.10 \\
\hline
\end{tabular}

Sources: World Bank Enterprise Survey and Committee on Statistics of Kazakhstan

\subsection{Dependent variable}

We adopt Scott and Lodge's (1985, p.3) definition of competitiveness as a “country's ability to create, to produce, to distribute, and to service the products in international trade while earning rising returns on its resources". Entering the international market helps firms to become more competitive in their domestic market (Autio et al., 2011; Brouthers et al., 2015) and to improve their performance and productivity ( $\mathrm{Lu}$ and Beamish, 2001). This is in line with the literature on measuring export performance as a percentage of exports in sales (Tookey, 1964), exporter/non-exporter (Bonaccorsi, 1992), and export profitability (Bilkey, 1982). We measure competitiveness, building on the export choice model (Cavusgil, 1984), and estimate the competitiveness gap as a difference between the actual and potential level of exports given a set of firm-level characteristics (Cavusgil and Naor, 1987).

\subsection{Independent variables}

The data is presented in three levels: firm-level (1059 firms), region-level, and countrylevel variables. We measure the effect of $L C P$ with a binary variable, which takes a value 
of one after the policy implementation in 2010 in Kazakhstan, and zero for the previous period.

Credit line is a dummy variable, which equals one if a firm has a line of credit or loan from a financial institution.

Firm size was included as a determinant of export performance (Moen, 1999). One of the arguments explaining why size has a positive effect on export performance is that exporting requires resources, such as financial or managerial (Lu and Beamish, 2001; Autio et al., 2011; Denk et al., 2012). Unlike larger firms, SMEs are less likely to have the required resources to enter the international market (Penrose, 1995; Lu and Beamish, 2001; Brouthers et al., 2009). Some literature shows a positive impact of firm size on export performance (Snavely et al., 1964; Doyle and Schommer, 1976; Bilkey and Tesar, 1977; Calof, 1994; Katsikeas and Morgan, 1994; Moen, 1999; Filatotchev et al., 2008), while other (Perkett, 1963; Tookey, 1964; Pla-Barber and Alegre, 2007) shows no relationship. These mixed results could be due to differences in measures of the firm size used and in the non-linear relationship between firm size and export performance. We use the number of full-time employees as a measure of size. In order to incorporate a non-linear relationship, we divided firms into three categories according to size (i.e., small, medium, and large), with small firms being a reference category.

Firm age is another important determinant of firm performance (Penrose, 1995), which is calculated as the difference between the year of survey and the year in which the firm began its operations in Kazakhstan. The literature shows a mixed impact of firm age on export performance. Some show a positive impact of firm age on export (Kaynak and Kuan, 1993; Dean et al., 2000), while other (Balabanis and Katsikea, 2003) shows no impact or a negative impact (Filatotchev et al., 2008).

Alliance is a binary variable that indicates whether the firm is part of an alliance. An alliance is characterised by cooperation among two or more firms that share knowledge and resources ( $\mathrm{Lu}$ and Beamish, 2001). Cooperation allows firms to access resources, such as financial or managerial, which they are otherwise lacking ( $\mathrm{Lu}$ and Beamish, 2001; Hillman et al., 2009). Availability of such resources determines the ability of firms to export (Lu and Beamish, 2001; Autio et al., 2011; Denk et al., 2012). Thus cooperation among firms positively affects their ability to export (Knight, 2000; Cegarra-Navarro, 2005; Jantunen et al., 2005; Street and Cameron, 2007).

Patent is a regional variable, which indicates the number of patents in a region.

International market access is a dummy variable, which equals one if a firm has an internationally recognised quality certification and zero otherwise.

Industry is a dummy variable, which indicates industry type, i.e., textiles; garments; food; metals and machinery; electronics; chemicals and pharmaceutics; wood and furniture; non-metallic and plastic materials; other manufacturing; other services; retail and wholesale trade; hotels and restaurants; auto and auto components; other: construction, transportation, etc.

The regional variables we included are: number of universities, unemployment ratio, transportation, agriculture, ICT (share of GDP), real GDP per capita (in 2005 prices), and SME density (number of SMEs per 1000 residents).

Firm-level data is provided by five geographical regions (North, South, West, East, and Center) based on data obtained from the Committee on Statistics of Kazakhstan (www.stat.gov.kz). This enabled us to control for region-specific characteristics. The F-test supported the inclusion of industry and region controls. 


\subsection{Estimation method}

We use the input-output Cobb-Douglas production function following Lichtenberg and Siegel (1991) to test our conceptual framework. Our model demonstrates the moderated effect of alliances in the relationship between LCPs and firm performance (1).

We use the $L C P S$ variable into each firm's function in addition to conventional inputs (labour and capital), with extra factors of production represented by institutional and industry measures (Estrin et al., 2013). As a result, LCPs are directly incorporated into a structural model, which allows us to capture changes in competitiveness when LCPs are implemented.

The model as the level of competitiveness is estimated as follows:

$$
p_{t} q_{i j t}-{\widehat{p_{t}}}_{i j t}=\delta_{0}+\delta_{1} M_{t}+\sum_{k=1}^{p} \rho_{k} F_{i t}+\sum_{l=1}^{q} \sigma_{l} R_{j t}+\sum_{n=1}^{s} \varphi_{n} M_{t} \times F_{i j t}+\varepsilon_{i j t}
$$

where ${\widehat{p_{t}}}_{i j t}$ is the predicted value of export from step 1 and $p_{t} q_{i j t}$ is the actual value of exports. We looked at the levels of correlation between indicators (Table A1) to ensure we obtained stable results (Wooldridge, 2002) (Table 3).

Table 3 Tobit estimation (model step two)

\begin{tabular}{|c|c|c|c|c|}
\hline Variables & (1) & (2) & (3) & (4) \\
\hline \multicolumn{5}{|c|}{ Firm-level characteristics } \\
\hline \multirow[t]{2}{*}{ Medium (20-99) } & $40.13 * *$ & $40.07 * *$ & $41.29 * *$ & $41.89 * *$ \\
\hline & (19.94) & $(19.91)$ & (19.99) & (20.09) \\
\hline \multirow[t]{2}{*}{ Large $(\geq 100)$} & $186.79 * * *$ & $186.78 * * *$ & $185.89^{* * *}$ & $186.21 * * *$ \\
\hline & $(14.18)$ & $(14.25)$ & $(14.35)$ & $(14.35)$ \\
\hline \multirow[t]{2}{*}{ Age } & $12.94 * * *$ & $12.96^{* * *}$ & $12.82 * * *$ & $12.83 * * *$ \\
\hline & $(1.47)$ & $(1.47)$ & $(1.47)$ & $(1.47)$ \\
\hline \multirow[t]{2}{*}{ Age-squared } & $-0.26^{* * *}$ & $-0.26^{* * *}$ & $-0.26^{* * *}$ & $-0.26^{* * *}$ \\
\hline & $(0.04)$ & $(0.04)$ & $(0.04)$ & $(0.04)$ \\
\hline \multirow[t]{2}{*}{ Quality certificate } & $-99.05^{* * *}$ & $-99.09 * * *$ & $-101.72 * * *$ & $-102.31 * * *$ \\
\hline & $(22.22)$ & $(22.23)$ & $(22.24)$ & $(22.24)$ \\
\hline \multirow[t]{2}{*}{ Manager experience } & $-2.62 * *$ & $-2.62 * *$ & $-2.62 * *$ & $-2.61 * *$ \\
\hline & $(1.12)$ & $(1.12)$ & $(1.12)$ & $(1.12)$ \\
\hline \multirow[t]{2}{*}{ CEO female } & $-104.20 * * *$ & $-104.14 * * *$ & $-104.47 * * *$ & $-104.53 * * *$ \\
\hline & (15.39) & (15.39) & (15.39) & $(15.45)$ \\
\hline \multirow[t]{2}{*}{ Web or email } & $1255.77 * * *$ & $1097.50 * * *$ & $1094.69 * * *$ & $1092.99 * * *$ \\
\hline & $(24.63)$ & $(24.61)$ & $(24.61)$ & $(24.62)$ \\
\hline \multirow[t]{2}{*}{ Alliance } & $83.50^{* * *}$ & $83.43^{* * *}$ & $127.60^{* * *}$ & $126.32 * * *$ \\
\hline & $(23.28)$ & $(23.26)$ & $(23.40)$ & $(23.40)$ \\
\hline \multirow[t]{2}{*}{ Credit line } & $-179.74 * * *$ & -179.74 & $-185.81^{* * *}$ & $-186.73^{* * *}$ \\
\hline & (16.6) & (16.8) & (16.98) & $(-11.01)$ \\
\hline
\end{tabular}


Table 3 Tobit estimation (model step two) (continued)

\begin{tabular}{|c|c|c|c|c|}
\hline Variables & (1) & (2) & (3) & (4) \\
\hline \multicolumn{5}{|c|}{ Regional-level characteristics } \\
\hline Patents & $\begin{array}{c}-19.74 * * * \\
(0.15)\end{array}$ & $\begin{array}{c}-24.89^{* * *} \\
(0.15)\end{array}$ & $\begin{array}{c}-22.75^{* * *} \\
(0.15)\end{array}$ & $\begin{array}{c}-22.61 * * * \\
(0.15)\end{array}$ \\
\hline Unemployment & $\begin{array}{c}191.15^{* * *} \\
(4.05)\end{array}$ & $\begin{array}{c}-864.52 * * * \\
(4.06)\end{array}$ & $\begin{array}{c}-752.09 * * * \\
(4.07)\end{array}$ & $\begin{array}{c}-743.69^{* * *} \\
(4.07)\end{array}$ \\
\hline Transportation, share of GDP & $\begin{array}{c}-79.33^{* * *} \\
(1.69)\end{array}$ & $\begin{array}{c}-183.90^{* * *} \\
(1.69)\end{array}$ & $\begin{array}{c}-176.76^{* * * *} \\
(1.69)\end{array}$ & $\begin{array}{c}-176.24 * * * \\
(1.69)\end{array}$ \\
\hline Agriculture, share of GDP & $\begin{array}{c}31.35 * * * \\
(1.56)\end{array}$ & $\begin{array}{c}101.27 * * * \\
(1.56)\end{array}$ & $\begin{array}{c}97.21 * * * \\
(1.57)\end{array}$ & $\begin{array}{c}96.91 * * * \\
(1.57)\end{array}$ \\
\hline ICT, share of GDP & $\begin{array}{c}3490.17^{* * *} \\
(72.31)\end{array}$ & $\begin{array}{c}4976.38^{* * *} \\
(74.01)\end{array}$ & $\begin{array}{c}4931.80^{* * *} \\
(75.64)\end{array}$ & $\begin{array}{c}4925.76^{* * *} \\
(75.67)\end{array}$ \\
\hline GDP per capita & $\begin{array}{c}152.48^{* * *} \\
(2.60)\end{array}$ & $\begin{array}{c}312.91 * * * \\
(2.60)\end{array}$ & $\begin{array}{c}304.18^{* * *} \\
(2.60)\end{array}$ & $\begin{array}{c}303.46^{* * *} \\
(2.61)\end{array}$ \\
\hline SME density per 1000 residents & $\begin{array}{c}-407.21^{* * *} \\
(3.87)\end{array}$ & $\begin{array}{c}-649.20^{* * *} \\
(3.88)\end{array}$ & $\begin{array}{c}-641.86^{* * *} \\
(3.89)\end{array}$ & $\begin{array}{c}-641.33^{* * * *} \\
(3.89)\end{array}$ \\
\hline Number of universities & $\begin{array}{c}4.47 * * * \\
(0.36)\end{array}$ & $\begin{array}{c}13.72 * * * \\
(0.36)\end{array}$ & $\begin{array}{c}13.04 * * * \\
(0.37)\end{array}$ & $\begin{array}{c}13.00 * * * \\
(0.37)\end{array}$ \\
\hline \multicolumn{5}{|c|}{ Country-level characteristics } \\
\hline LCP (Hypothesis 1) & & $\begin{array}{c}1699.64^{* * *} \\
(19.92)\end{array}$ & $\begin{array}{c}1453.56^{* * *} \\
(22.27)\end{array}$ & $\begin{array}{c}1444.18^{* * *} \\
(22.30)\end{array}$ \\
\hline LCP $\times$ Alliance (Hypothesis 2) & & & $\begin{array}{c}-83.86^{* * *} \\
(22.16)\end{array}$ & $\begin{array}{c}-81.18 * * * \\
(22.17)\end{array}$ \\
\hline Constant & $\begin{array}{c}-2501.45^{* * *} \\
(24.63)\end{array}$ & $\begin{array}{c}5204.42 * * * \\
(24.61)\end{array}$ & $\begin{array}{c}4419.30 * * * \\
(24.61)\end{array}$ & $\begin{array}{c}4367.51 * * * \\
(24.62)\end{array}$ \\
\hline $\begin{array}{l}\text { Test on joint significance of age } \\
\text { and age-squared } F(2,1061)\end{array}$ & $8262 * * *$ & $7646^{* * *}$ & $7677 * * *$ & $7131 * * *$ \\
\hline $\begin{array}{l}\text { Test on joint significance of industry } \\
\text { dummies } F(9,1061)\end{array}$ & $2745^{* * *}$ & $1821^{* * *}$ & $1660 * * *$ & $1661 * * *$ \\
\hline $\begin{array}{l}\text { Test on joint significance of region } \\
\text { dummies } F(7,1061)\end{array}$ & $3000 * * *$ & $3000 * * *$ & $3000 * * *$ & $3000 * * *$ \\
\hline Pseudo R-squared & 0.15 & 0.15 & 0.15 & 0.15 \\
\hline Observations & 1059 & 1059 & 1059 & 1059 \\
\hline
\end{tabular}

$* p<0.1, * * p<0.05, * * * p<0.01$. Standard errors in parentheses. Regions and industries are controlled. Reference category size: small (1-20 full-time employees).

Source: World Bank Enterprise Survey and Committee of Statistics of Kazakhstan 


\section{Results and discussion}

We tested hypotheses using firms' competitiveness gap as a dependent variable ${ }^{1}$ (equation (6)). Due to a censored dependent variable, Tobit estimation was applied. Table 2 illustrates the main estimated results and relationships, building on Hypotheses 1 and 2.

LCPs are positively associated with firm competitiveness (Bradshaw and Blakely, 1999; Kalyuzhnova et al., 2016). Overall, firms in Kazakhstan were found to be more competitive internationally during the period after implementation of LCP in 2010 (Hypothesis 1).

Our results also demonstrate that firms in alliances are more competitive (Jantunen et al., 2005; Street and Cameron, 2007; Brouthers et al., 2015) $(\beta=126.32, p<0.05)$. At the same time, the value of the interaction coefficient is negative, which means that firm competitiveness is negatively associated with being part of an alliance under LCP implementation (81.18\%). The net effect is $45.14 \%$ (i.e., $126.32-81.18 \%$ ).

Thus our Hypothesis 2 is supported. Firms that are part of an alliance are likely to be less competitive after implementation of LCP. This result confirms that although firms in alliances are more competitive they may not fully benefit from LCP. As a consequence, the economy overall would not reach the level of sustaining $L C$. The role of government at this stage is in engaging all alliance members in participating in LCP and providing more informational support within the organisation - in particular facilitating procurement and access to information. It may be the case that databanks and legal support are limited within the alliance, which then prevents the economy from achieving market-creating $L C$.

LCPs have become important boundary criteria to ensure technology transfer to domestic firms; in particular, this is relevant for new and prospective industries. In relation to firms that are part of alliances, the government toolbox is in creating an optimal economic basis (without harming the public or market players) and an emerging entrepreneurship ecosystem before the economy moves to the third stage, market creating $L C$. For example, efficient technology transfer from partners may become a competitive advantage in winning procurement contracts by domestic firms.

\section{Conclusion}

The interplay between LPCs and firm competitiveness is an emerging area of scholarship (Chu, 2011; Kalyuzhnova et al., 2016). In international markets where competition is strong, firms that are part of a group is more likely to demonstrate a higher level of competitiveness. Analysis of 1059 firms in Kazakhstan over the two periods, 2009 and 2013, outlines the importance of alliances as a conduit of knowledge to performance (Malerba and Nelson, 2011).

The outcomes and main contributions of this study are as follows. First, it responds to a call for a more rigorous analysis of competitiveness effects in the interplay between LCPs, alliance. Second, it tests the ability of a firm that is part of an alliance benefit from LCPs. 
Building on prior research we provided theoretical conceptualisation and empirical evidence on the role that alliances play in leveraging LCPs on firm competitiveness.

We recognise several potential limitations of this research. First, the Enterprise Survey data does not include the $O \& G$ sector. Although we acknowledge it as a limitation, this sector is oligopolistic and dominated by very few large companies (such as Tengizchevroil, KazMunaiGas, etc.) therefore inclusion of data from the large $\mathrm{O} \& \mathrm{G}$ companies could negatively affect the robustness of the expected results. Our data distribution would be considerably skewed toward a greater role of alliances in international competitiveness, but also need to be weighted by the number of employees or turnover. This would impose additional assumptions on our results.

Second, the effect of LCP is measured with a binary variable (equals 0 in 2009, before the policy implementation; and 1 in 2013, after the policy). Other country-level variables could not be included due to multicollinearity problems.

Further research calls for understanding the role of alliances at the more advanced stages of LCPs, sustaining $L C$ and efficiency $L C$, as well as investigating their role in leveraging national industrial and public policies. This would answer the question whether the alliance is a more powerful tool, over time, to facilitate competitiveness, nationally and internationally, within the context of LCPs.

\section{Acknowledgement}

This work was supported by the British Council Newton Fund (Newton - Al-Farabi Partnership Programme, grant number 172697816, 2015).

\section{References}

Audretsch, D.B., Belitski, M. and Desai, S. (2015) 'Entrepreneurship and economic development in cities', Annals of Regional Science, Vol. 55, No. 1, pp.33-60.

Autio, E., George, G. and Alexy, O. (2011) 'International entrepreneurship and capability development: qualitative evidence and future research directions', Entrepreneurship Theory and Practice, Vol. 35, No. 1, pp.11-37.

Balabanis, G.I. and Katsikea, E.S. (2003) 'Being an entrepreneurial exporter: does it pay?', International Business Review, Vol. 12, No. 2, pp.233-252.

Bastida, E.A. (2014) 'From extractive to transformative industries: paths for linkages and diversification for resource-driven development', Mineral Economics, Vol. 27, Nos. 2-3, pp.73-87.

Belitski, M. and Desai, S. (2016) 'Creativity, entrepreneurship and economic development: city-level evidence on creativity spillover of entrepreneurship', The Journal of Technology Transfer, Vol. 41, No. 6, pp.1354-1376.

Bilkey, W.J. (1982) 'Variables associated with export profitability', Journal of International Business Studies, Vol. 13, No. 2, pp.39-55.

Bilkey, W.J. and Tesar, G. (1977) 'The export behavior of smaller-sized Wisconsin manufacturing firms', Journal of International Business Studies, Vol. 8, No. 1, pp.93-98.

Bonaccorsi, A. (1992) 'On the relationship between firm size and export intensity', Journal of International Business Studies, Vol. 24, No. 4, pp.605-636. 
Bradshaw, T.K. and Blakely, E.J. (1999) 'What are 'third-wave' state economic development efforts? from incentives to industrial policy', Economic Development Quarterly, Vol. 13, No. 3, pp.229-244.

Brouthers, K.D., Nakos, G. and Dimitratos, P. (2015) 'SME entrepreneurial orientation, international performance, and the moderating role of strategic alliances', Entrepreneurship Theory and Practice, Vol. 39, No. 5, pp.1161-1187.

Brouthers, L.E., Nakos, G., Hadjimarcou, J. and Brouthers, K.D. (2009) 'Key factors for successful export performance for small firms', Journal of International Marketing, Vol. 17, No. 3, p. 21338 .

Calof, J.L. (1994) 'The relationship between firm size and export behavior revisited', Journal of International Business Studies, Vol. 25, No. 2, pp.367-387.

Capello, R. and Lenzi, C. (2014) 'Spatial heterogeneity in knowledge, innovation, and economic growth nexus: conceptual reflections and empirical evidence', Journal of Regional Science, Vol. 54, No. 2, pp.186-214.

Cavusgil, S.T. (1984) 'Organizational characteristics associated with export activity', Journal of Management Studies, Vol. 21, No. 1, pp.3-22.

Cavusgil, S.T. and Naor, J. (1987) 'Firm and management characteristics as discriminators of export marketing activity', Journal of Business Research, Vol. 15, No. 3, pp.221-235.

Chu, W-W. (2011) 'How the Chinese government promoted a global automobile industry', Industrial and Corporate Change, Vol. 20, No. 5, pp.1235-1276.

Dean, D.L., Mengüç, B. and Myers, C. P. (2000) 'Revisiting firm characteristics, strategy, and export performance relationship: a survey of the literature and an investigation of New Zealand small manufacturing firms', Industrial Marketing Management, Vol. 29, No. 5, pp.461-477.

Deardorff, A.V. and Stern, R.M. (1997) Measurement of Non-Tariff Barriers, OECD Economics Department Working Papers, No. 179, OECD Publishing, Paris, DOI: http://dx. doi. org/10.1787/568705648470 Accessed 06.05.16.

Denk, N., Kaufmann, L. and Roesch, J.F. (2012) 'Liabilities of foreignness revisited: a review of contemporary studies and recommendations for future research', Journal of International Management, Vol. 18, No. 4, pp.322-334.

Devlin, G. and Bleackley, M. (1988) 'Strategic alliances: guidelines for success', Long Range Planning, Vol. 21, No. 5, pp.18-23.

Díaz-Cayeros, A., Magaloni, B. and Ruiz-Euler, A. (2014) 'Traditional governance, citizen engagement, and local public goods: evidence from Mexico', World Development, Vol. 53, pp.80-93.

Doyle, R.W. and Schommer, N.A. (1976) The Decision to Export: Some Implications [Study commissioned by the Minnesota District Export Council], Minnesota District Export Council, St. Paul.

Draulans, J. and Volberda, H.W. (2003) 'Building alliance capability: management techniques for superior alliance performance', Long Range Planning, Vol. 36, No. 2, pp.151-166.

Eisinger, P. (1995) 'State economic development in the 1990s: politics and policy learning', Economic Development Quarterly, Vol. 92, pp.146-158.

Enderwick, P. (2011) 'Understanding the rise of global protectionism', Thunderbird International Business Review, Vol. 53, No. 3, pp.325-336.

Erramilli, M.K. (1991) 'The experience factor in foreign market entry behavior of service firms', Journal of International Business Studies, Vol. 22, pp.479-501.

Estrin, S., Korosteleva, J. and Mickiewicz, T. (2013) 'Which institutions encourage entrepreneurial growth aspirations?' Journal of Business Venturing, Vol. 28, No. 4, pp.564-580.

Farooki, M. and Kaplinsky, R. (2014) 'Promoting diversification in resource-rich economies', Mineral Economics, Vol. 27, No. 2, pp.103-113. 
Fasano, U. (2002) Review of the Experience with Oil Stabilisation and Savings Funds in Selected Countries, IMF Working Paper, WP/00/112. Washington: International Monetary Fund.

Filatotchev, I., Stephan, J. and Jindra, B. (2008) 'Ownership structure, strategic controls and export intensity of foreign-invested firms in transition economies', Journal of International Business Studies, Vol. 39, No. 7, pp.1133-1148.

Greene, W.H. (2003). Econometric Analysis. Pearson Education India, Delhi.

Grossman, G.M. (1981) 'The theory of domestic content protection and content preference', Quarterly Journal of Economics, Vol. 96, No. 4, pp.583-603.

Gylfason, T., Tryggvi, T.H. and Zoega, G. (1999) 'A mixed blessing: natural resources and economic growth', Macroeconomic Dynamics, Vol. 3, No. 2, pp.204-225.

Heum, P., Quale, C., Karlsen, J.E., Kragha, M. and Osahon, J. (2003) Enhancement of Local Content in the Upstream Oil and Gas Industry in Nigeria: A Comprehensive and Viable Policy Approach. SNF Report No. 25/03. Institute for Research in Economics and Business Administration $(S N F)$, Bergen, Norway, August.

Hillman, A.J., Withers, M.C. and Collins, B.J. (2009) 'Resource dependence theory: a review', Journal of Management, Vol. 35, No. 6, pp.1404-1427.

Hipkin, I. and Naudé, P. (2006) 'Developing effective alliance partnerships: lessons from a case study', Long Range Planning, Vol. 39, No. 1, pp.51-69.

Hunter, T. (2014) 'Law and policy frameworks for local content in the development of petroleum resources: Norwegian and Australian perspectives on cross-sectoral linkages and economic diversification', Mineral Economics, Vol. 27, Nos. 2-3, pp.115-126.

Jantunen, A., Puumalainen, K., Saarenketo, S. and Kyläheiko, K. (2005) 'Entrepreneurial orientation, dynamic capabilities and international performance', Journal of International Entrepreneurship, Vol. 3, No. 3, pp.223-243.

Kalyuzhnova, Y. (2008) Economics of the Caspian Oil and Gas Wealth: Companies, Governments, Policies, Palgrave MacMillan, Basingstoke, Hampshire, UK.

Kalyuzhnova, Y. and Lee, J. (2014) 'China and Kazakhstan 's oil and gas partnership at the start of the twenty-first century', Emerging Markets Finance and Trade, Vol. 50, No. 5, pp.206-221.

Kalyuzhnova, Y. and Patterson, K. (2016) 'Kazakhstan: long-term economic growth and the role of the oil sector', Comparative Economic Studies, Vol. 58, No. 1, pp.93-118.

Kalyuzhnova, Y., Nygaard, C.A., Omarov, Y. and Saparbayev, A. (2016) Local Content Policies in Resource Rich Countries, Palgrave MacMillan, Basingstoke, Hampshire, UK.

Katsikeas, C.S. and Morgan, R.E. (1994) 'Differences in perceptions of exporting problems based on firm size and export market experience', European Journal of Marketing, Vol. 28, No. 5, pp.17-35.

Kaynak, E. and Kuan, W. K. Y. (1993) 'Environment, strategy, structure, and performance in the context of export activity: an empirical study of Taiwanese manufacturing firms', Journal of Business Research, Vol. 27, No. 1, pp.33-49.

Knight, G. (2000) 'Entrepreneurship and marketing strategy: the SME under globalization', Journal of International Marketing, Vol. 8, No. 2, 12-32.

Korosteleva, J. and Mickiewicz, T. (2011) 'Startup finance in the age of globalisation', Emerging Markets Finance and Trade, Vol. 47, No. 3, pp.23-49.

Lichtenberg, F.R. and Siegel, D. (1991) 'The impact of R\&D investment on productivity: new evidence using linked R\&D-LRD data', Economic Inquiry, Vol. 29, No. 2, pp.203-229.

Lin, J. and Chang, H-J. (2009) 'Should industrial policy in developing countries conform to comparative advantage or defy it? a debate between Justin Lin and Ha-Joon Chang', Development Policy Review, Vol. 27, No. 5, pp.483-502.

Lu, J.W. and Beamish, P. W. (2001) 'The internationalization and performance of SMEs', Strategic Management Journal, Vol. 22, Nos. 6-7, pp.565-586. 
Lu, Y., Zhou, L., Bruton, G. and Li, W. (2010) 'Capabilities as a mediator linking resources and the international performance of entrepreneurial firms in an emerging economy', Journal of International Business Studies, Vol. 41, No. 3, pp,419-436.

Malerba, F. and Nelson, R. (2011) 'Learning and catching up in different sectoral systems: evidence from six industries', Industrial and Corporate Change, Vol. 20, No. 6, pp.1645-1675.

Moen, Ø. (1999) 'The relationship between firm size, competitive advantages and export performance revisited', International Small Business Journal, Vol. 18, No. 1, pp.53-72.

Pan, Y., Li, S. and David, K.T. (1999) 'The impact of order and mode of market entry on profitability and market share', Journal of International Business Studies, Vol. 30, No. 1, pp.81-103.

Pekar, P. and Allio, R. (1994) 'Making alliances work: guidelines for success', Long Range Planning, Vol. 27, No. 4, pp.54-65.

Penrose, E.T. (1995) The Theory of the Growth of the Firm, Oxford University Press, USA.

Perkett, W. (1963) An Analysis of the Obstacles to Increased Foreign Trade Which Confront British Columbia Industrial Machinery Manufacturers, Unpublished Doctoral Dissertation, University of Washington, Seattle.

Pla-Barber, J. and Alegre, J. (2007) 'Analysing the link between export intensity, innovation and firm size in a science-based industry', International Business Review, Vol. 16, No. 3, pp.275-293.

Platteau, J. P. and Gaspart, F. (2003) 'The risk of resource misappropriation in community-driven development', World Development, Vol. 31, No. 10, 1687-1703.

Scott, B. R. and Lodge, G. C. (1985) 'US competitiveness in the world economy', The International Executive, Vol. 27, No. 1, p.26.

Snavely, W.P., Weiner, P., Ulbrich, H.H. and Enright, E.J. (1964) Export Survey of the Greater Hartford Area, University of Connecticut.

Street, C.T. and Cameron, A.F. (2007) 'External relationships and the small business: a review of small business alliance and network research', Journal of Small Business Management, Vol. 45, No. 2, pp.239-266.

Tookey, D.A. (1964) 'Factors associated with success in exporting', Journal of Management Studies, Vol. 1, No. 1, pp.48-66.

Tordo, S., Warner, M., Manzano, O.E. and Anouti, Y. (2013) Local Content in the Oil and Gas Sector: A World Bank Study. World Bank, Washington, DC.

Wooldridge, J.M. (2002) Econometric Analysis of Cross Section and Panel Data, The MIT Press, Cambridge, MA.

\begin{abstract}
Note
${ }^{1}$ Important determinants of firm's competitiveness are firm age and size, the level of regional unemployment and ICT production. Large and medium firms are more competitive than small firms which are restricted "to certain types of opportunities due to their size" (Penrose, 1995, p.215). These results support the claim that larger firms have more resources available to expand in a foreign market, while SMEs' lack of resources restrict them from the international market (Lu and Beamish, 2001; Brouthers et al., 2009). This effect is related to the availability of resources, such as financial and managerial, which allow larger firms to be more competitive. Results show a non-linear relationship between age and competitiveness, supporting the 'learning by doing' argument, i.e., experience has a positive impact on export performance at the initial stage of market entry (Davidson, 1980; Erramilli, 1991).
\end{abstract}




\section{Appendix}

Table A1 Correlation matrix

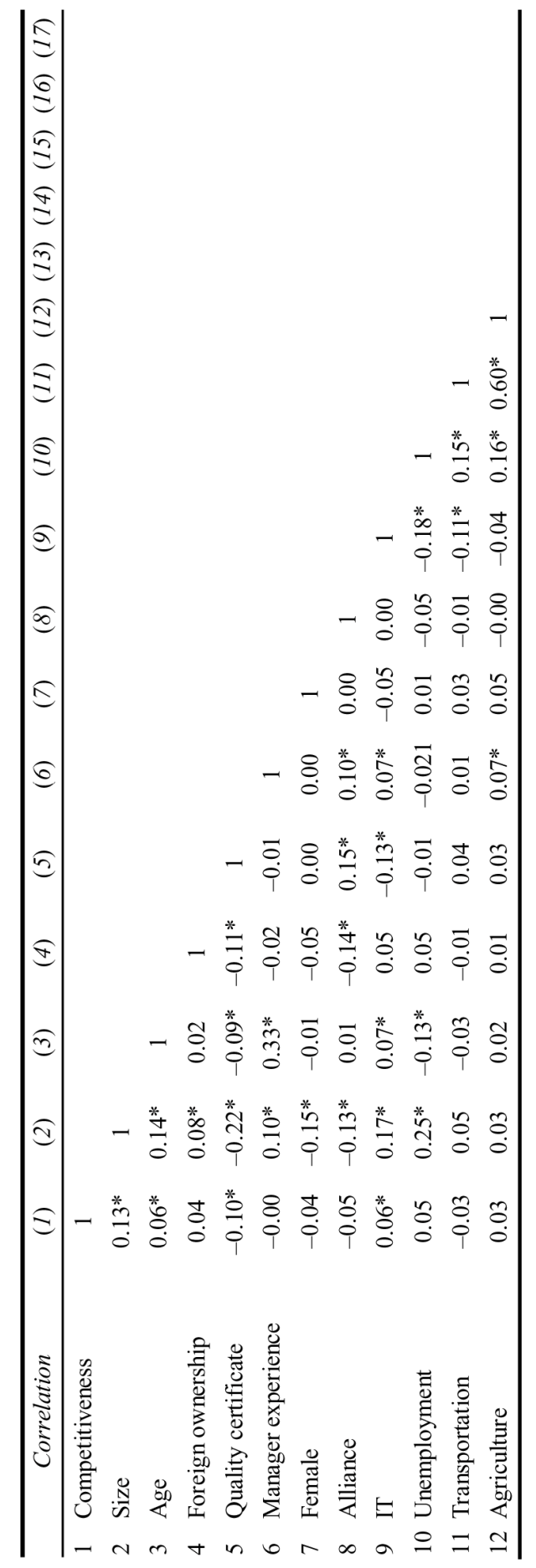


Table A1 Correlation matrix (continued)

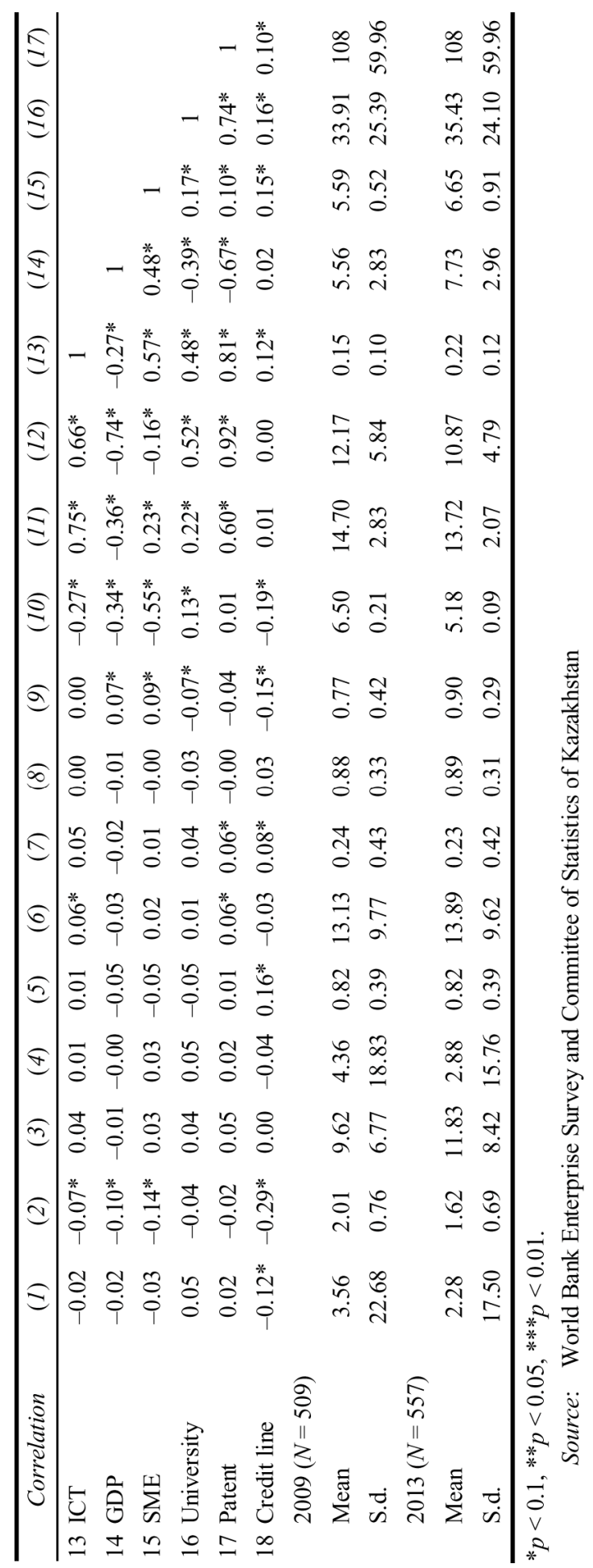

